\title{
Scoring the Open Source Learning Management Systems
}

\author{
Li-Jen Y. Shannon and Marilyn Rice
}

\begin{abstract}
Based on the demands of online teaching and learning programs from various levels of educational systems and enterprises in the past decade, there are many open source of learning management systems from which to choose. In order to select the most feasible and appropriate learning management software, it requires the administrators to analyze and assess the needs from their own institutions and follow up with the comparison of available software. This study investigated the vital critique items through various popular open source of learning management systems. Three critique categories were formed including Course Building Functions, Server Functions, and Training and Service. This research paper will be focused on reporting two out of three categories: Course Building and the Training and Service categories. There were eight items suggested under the category of Course Building Functions. Six items were scrutinized for the category of Server Functions. The Training and Service category included three studied items. The suggested critique items and categories from this research will serve the top managers in assisting their decision-making for implementing a tool which would be the best fit for their specific needs.
\end{abstract}

Index Terms-Learning management system, open source LMS, online teaching, online learning.

\section{INTRODUCTION}

Evolving with the technology trends, there has been a high demand of online teaching and learning programs from various levels of educational systems and enterprises in the past decade. Close to seventy percent of higher education institutions from more than 2,800 US colleges and universities reported that online education was critical to their long-term strategy [1]. Also, 46 percent of organizations use virtual teams in their workplace which is based on a 335 participated organizations [2]. To fulfill the needs of offering online learning environment, numerous popular open source learning management systems (LMS) have been adopted either free of charge or paid with a certain amount of technical fee by the institutions. During the adoption process of selecting the most feasible and appropriate LMS, it becomes a very tedious and difficult task for the administrators. The evidence showed that the concerns of lacking faculty acceptance while promoting online education became one of critical elements for their success [1]. It would require the administrators to analyze and assess the needs from their own institutions. Following up with a detailed comparison of potential LMS would be ideal to include debate and testing if

Manuscript received December 10, 2015; revised April 12, 2016.

Li-Jen Shannon is with the Department of Computer Science, Sam Houston State University, Huntsville, TX 77340, USA (e-mail: lys001@shsu.edu).

Marilyn Rice is with the Department of Curriculum and Instruction, Sam Houston State University, Huntsville, TX 77340, USA (e-mail: edu_mpr@shsu.edu). the institution had efficient manpower and time.

This study investigated various internationally popular LMS including Edmodo, Google Apps for Education, MOOC, Moodle, OLAT, and Sakai. These popular software offer easy access to demonstration and provide details of tool functionality. From the ample of technical critiques and try out from the demonstration courses, this research filtered out the common input and merged them into three critique categories which are Course Building Functions (CBF), Server Functions (SF), and Training and Service (TS). For the Course Building Functions category, there were eight items compared for details of course quality control, interactive tools, template courses, grade book interfaces, social network subscription, calendar builder, course assessment, and resources sharing. The available functions of monitoring criteria, interacting interfaces, and assessing tools were carefully scrutinized in this category.

To investigate the Server Functions category, there were six items compared for details of file size control, enrollment process, plugins and access control, online/offline function, analytics function, and course archiving function. It is vital for the users and the institutions to have a freely accessible and quick responding server all the time. The transmission speed and storage capacity with easy access while online or offline have been evaluated in this category. However, this category will not be reported within this paper. It will be reported as a separated paper of our research project.

The Training and Service category included the three studied items of user training materials, developer forums and tips, and technical support. For new users, it is important to provide the needed training, guideline, and support. Moreover, considering whether in-house technicians and management would be needed or not, the potential selected LMS would be critiqued to analyze both the advantages and disadvantages of its design, and also to review it from the perspective of its benefits in applied modern technology.

We thrive to form an easy critique formula from this research, in order to serve the top managers in assisting their decision-making for adopting the best LMS which would fulfill their specific needs.

\section{Popular Learning Management System}

\section{A. Learning Management System}

LMS acts in administering to facilitate all content groups and learning activities, such as test creation, examination, evaluation of lessons, and interactive communication between the lecturers and the students [3].The LMS and tools can be used as mechanisms for creating a platform for student investment and ownership in the learning process [4]. While depending on the software to bridge the instructors and 
learners' perception in learning, there are factors which impact on the success of applying LMS. Multimedia based e-learning system has been strongly recommended to integrate analysis, design, technical requirements, content development, production and integration, implementation, and evaluation [5]. The sections below will highlight some factors of how LMS presented themselves in this online learning environment.

\section{B. Edmodo}

Edmodo provides a learning environment to connect and collaborate among students, parents, administrators, and instructors [6]. Edmodo provides a planner tool as a personal, automatically updated organizational tool which eases the weekly or monthly preparation for the learning unit [7]. ISTE reported the benefits for education including privacy for digital learning, empowerment of personalized internet, collaboration to share ideas and work together, professional development, organization of everything in one place, differentiation of custom-fit for individual, authentic communication for real audiences, and engagement for greater classroom efficiency and rigor [8].

\section{Google Apps for Education}

Google Apps for Education (GAFE) is a suite of free productivity tools for classroom collaboration [9]. This cloud technology allows collaboration in real-time by using any device. GAFE provides communication and collaboration apps include Gmail, Calendar, Drive Docs and Sites, and a GAFE account unlocks access to other collaborative tools supported by Google [10]. The three main benefits of using GAFE are: saves school budget, boosts academic performance and motivation, and prepares students for digital communication in the real world [11].

\section{MOOCs}

Massive Open Online Courses (MOOCs) platforms have altered higher education leaders' perceptions and plans for offering online learning environment [12]. MOOC offers free courses for anyone who has internet connection around the world [12]. The institutions, businesses, and teachers can build and host courses for the world to take. There are various open source platforms which the faculty can create a MOOC course, such as the for-non-profit supported Coursera, NovoEd, and OpenEdX offering different features for the faculty to select from [13]. Generally, the freedom of teaching was shared in MOOCs through levels of creativity, discussion communities, control for special needs, online conferencing, and commitment to experimentation and evolution [14].

\section{E. Moodle}

Moodle is an open source with plugins platform providing the tools for educators to develop and manage course online. The founding principle of Moodle is the social network to offer forums, wiki, and various networking features [15]. The most used function among all of the features is collaborative learning which allows the educators to accomplish the common tools, such as create roles and give permission, add discussion forums, moderate discussions, subscribe and receive notifications, attach resources. It also allows the educators to rate forums [16]. However, Moodle requires that administrators host their own LMS which applies to e-commerce as well [17].

\section{F. OLAT}

Online Learning and Training (OLAT) is an open source driven by the University of Zurich to offer diverse functionality for the needs in web-based learning and training, such as perform e-assessments and questionnaires, implement multimedia forms, provide interactive and intuitive platform, and create collaborative tools for communication [18].The aim of OLAT is that knowledge should be shared with simple and enjoyable way for everyone at all times and everywhere [19]. Therefore, the collaboration function of OLAT has been giving lectures a transferring platform for knowledge.

\section{G. Sakai}

Sakia was developed by Indiana University, University of Michigan, MIT, and Stanford to offer a platform around the world for supporting instruction, research, and outreach [20]. The standard set of tools provide versatile support for teaching and learning, communication, collaboration, e-portfolios, content and media integration, and administration [21]. In addition, unlike typical Java web apps, Sakai shares third-party dependencies with each other. The plugin adds facilities to act as an open source collaboration system for educational institutions [22].

\section{Methodology}

The main purpose of this research is to form a basic critique mechanism by reviewing the uniqueness of current popular LMS internationally. The software listed in the previous section, each LMS is reviewed from the official site to the demonstration courses, blogs, and literature reviews. We obtained the common terminologies and grouped the similar functions together into categories. The LMS comparison table created by Electronic Educational Environment was also utilized in this research to review and support the important items formed [23]. We do not critique or compare those popular LMS, but we do collect the effective tools and functions which could be used as future comparison purpose. The following two sections will devoteour suggested critique categories which are also listed in the appendix table.

\section{COURSE BUILDING FunCTIONS (CBF)}

\section{A. Course Quality Control}

"Easy use of course quality control which was monitored by the required process of course approval criteria, copyright statement...etc" The quality assurance is handled by the administrators to offer the best outcome of learning environment. The access code and software monitoring process would be a safe guard to achieve the quality control [24]-[27].

\section{B. Interactive Tools}

"Availability of interactive tools which could be incorporated in the LMS." The LMS is capable of allowing the users sharing resources and multimedia within activities, 
such as integrating with What You See Is What you Get (WYSIWYG) editors, Learning tools Interoperability (LTI), Sharable Content Object Reference Model (SCORM), embedded external resources, and other social networks [28]-[32].

\section{Template Courses}

"Samples of template courses developed." The LMS has the ability to allow administrators providing uniformity of courses or allow the users to create their own course by importing specific items [15], [33], [34].

\section{Gradebook Interfaces}

"Easy use of setting up gradebook." A simple and basic tool allows the educators to manage the grade book. The LMS provides the import and export functions for the educators and students [27], [31], [35]-[37].

\section{E. Social Network Subscription}

"Easy use of available social network and ability for subscription." The LMS builds in the communication network where the subscription function is available to notify the users when any updated postings are available for the various types of social networks [15], [37]-[40].

\section{F. Calendar Builder}

"Easy use of course calendar, schedule, and due date management system."This function is not commonly provided by most of LMS, but it provides the ability of building a planer and exporting outside calendar assisting in educators to manage their course work in one location [27], [37], [41], [42].

\section{G. Course Assessment}

"Easy use of assessment tools available for this LMS." This function is neither commonly applied to the open source LMS The specific features in evaluating the course would be a great tool to have, such as quiz engine, feedback from the quiz, and peer assessment functions [17], [27], [37], [43].

\section{H. Resources Sharing.}

"Easy use of how the course resources can be posted, stored, and organized."Whether the resources would be stored in the institution sites or the provided cloud space would need to be investigated while comparing the LMS [37], [44], [45].

\section{TRAINING AND SERVICE (TS)}

\section{A. Training Materials}

"Evidence of how the training materials are provided for new users."It is found that the LMS inspires better teaching and learning when the training materials are available. Especially, a self-service tool is available for the students to complete the courses, certificates, or academic credit [27], [45]-[50].

\section{B. Developer Forums and Tips}

"Place holder of how the developer provides guidelines and help." The discussions about the open source with coding details, guidelines, and tips have been appreciated by sharing with the users [27], [48], [51], [52].

\section{Technical Support}

"Provide central support and services." Whatever the LMS would offer either Support ticket Submission, or a live line help, the users value this service greatly [27], [45], [46], [49], [53]-[55].

\section{CONCLUSIONS}

We believe that additional critique items could be merged in and considered as vital elements along with the evolving technology over time; such as including the ability to scale up, robust, and incorporated with innovative ideas of teaching online courses. E-learning provides instant, convenient, flexible, and long-distance learning to people, however, a successful key is its continued intention to thrive along with the development of digital technology [56]. The LMS Critique Scoring Sheet suggested below in the appendix would provide the institution a guideline of understanding what the faculty and students' value in using LMS. A need analysis would be helpful to guide the top managers using the scoring sheet to determinate the direction of adopting a LMS.

It's suggested that a pre-evaluation stage should be conducted before comparing the potential LMS. The students, faculty, staffs, and administrators are the valuable resources to assist in the need analysis. Finding out the LMS service and need from the users' points would cut down a lot of time for perusing the "buy-in" from the campus. For example, if the pre-evaluation results showed that there was a high expectation in the category of Training and Service and a low value in Server Function (which will be reported in another paper), the top managers might need to consider switching the focus from the conflict views of Information Technology (IT) Department on the server related concerns to the training related programs. If specific items appeared to have high expectations from the Course Building Functions category, moreover, the top managers would consider ensuring that the potential LMS should offer those "expected" functions for the campus users.

In this paper, we suggested 11 critique items which eight are in the category of Course Building Functions and three are in the Training and Service category. Disregarding whether a commercial LMS or an open source LMS would be considered for the entire campus or just a small program, we do believe that a need analysis should be conducted first before contributing the time and manpower in selecting a best-fit LMS.

Many institutions had experienced the process of switching LMS campus-wide. The hardship encountered with the faculty, students, and IT staffs could be eliminated from the beginning of critiquing the LMS. We thrive to create a mechanism for our future LMS selection process and transform the procedure as easy as how the users evaluated their needs in using LMS.

APPENDIX

\begin{tabular}{|l|l|l|}
\hline \multicolumn{3}{|c|}{ LMS Critique Scoring Sheet } \\
\hline \multirow{3}{*}{ Critique Items } & \multicolumn{1}{|c|}{ Description } & Score of \\
& & Meeting the \\
& & needs \\
& & $0-5$ (5 being the \\
\hline
\end{tabular}




\begin{tabular}{|c|c|c|}
\hline & & highest value) \\
\hline \multicolumn{3}{|c|}{ Course Building Functions } \\
\hline $\begin{array}{l}\text { Course Quality } \\
\text { Control }\end{array}$ & $\begin{array}{l}\text { Easy use of course quality control } \\
\text { which was monitored by the } \\
\text { required process of course approval } \\
\text { criteria, copyright statement...etc }\end{array}$ & \\
\hline Interactive Tools & $\begin{array}{l}\text { Availability of interactive tools } \\
\text { which could be incorporated in the } \\
\text { LMS. }\end{array}$ & \\
\hline $\begin{array}{l}\text { Template } \\
\text { Courses }\end{array}$ & $\begin{array}{l}\text { Samples of template courses } \\
\text { developed. }\end{array}$ & \\
\hline $\begin{array}{l}\text { Gradebook } \\
\text { Interfaces }\end{array}$ & $\begin{array}{l}\text { Easy use of setting up the } \\
\text { gradebook }\end{array}$ & \\
\hline $\begin{array}{l}\text { Social Network } \\
\text { Subscription }\end{array}$ & $\begin{array}{l}\text { Available social network and ability } \\
\text { for subscription. }\end{array}$ & \\
\hline $\begin{array}{l}\text { Calendar } \\
\text { Builder }\end{array}$ & $\begin{array}{l}\text { Easy use of course calendar, } \\
\text { schedule, and due date management } \\
\text { system. }\end{array}$ & \\
\hline $\begin{array}{l}\text { Course } \\
\text { Assessment }\end{array}$ & $\begin{array}{l}\text { Easy use of assessment tools } \\
\text { available for this LMS. }\end{array}$ & \\
\hline $\begin{array}{l}\text { Resources } \\
\text { Sharing }\end{array}$ & $\begin{array}{l}\text { Easy use of how the course } \\
\text { resources can be posted, stored, and } \\
\text { organized. }\end{array}$ & \\
\hline \multicolumn{3}{|c|}{ Server Functions (Not reported in this paper) } \\
\hline File Size Control & $\begin{array}{l}\text { Amount of the server capacity for } \\
\text { file transmission \& storage. }\end{array}$ & \\
\hline $\begin{array}{l}\text { Enrollment } \\
\text { Process }\end{array}$ & $\begin{array}{l}\text { Easy use of how the learners access } \\
\text { to the course platform. }\end{array}$ & \\
\hline $\begin{array}{l}\text { Plugins And } \\
\text { Access Control }\end{array}$ & $\begin{array}{l}\text { Provide plugins infrastructure and } \\
\text { access control are available. }\end{array}$ & \\
\hline $\begin{array}{l}\text { Online/Offline } \\
\text { Function }\end{array}$ & Offline capabilities. & \\
\hline $\begin{array}{l}\text { Analytics } \\
\text { Function }\end{array}$ & $\begin{array}{l}\text { Easy use of learning data from the } \\
\text { collected course information }\end{array}$ & \\
\hline $\begin{array}{l}\text { Course } \\
\text { Archiving } \\
\text { Function }\end{array}$ & $\begin{array}{l}\text { Easy use of courses rollover and } \\
\text { archive. }\end{array}$ & \\
\hline \multicolumn{3}{|c|}{ Training and Service } \\
\hline $\begin{array}{l}\text { User Training } \\
\text { Materials }\end{array}$ & $\begin{array}{l}\text { Evidence of how the training } \\
\text { materials are provided for new } \\
\text { users. }\end{array}$ & \\
\hline $\begin{array}{l}\text { Developer } \\
\text { Forums and Tips }\end{array}$ & $\begin{array}{l}\text { Place holder of how the developer } \\
\text { provides guidelines and help. }\end{array}$ & \\
\hline $\begin{array}{l}\text { Technical } \\
\text { Support }\end{array}$ & $\begin{array}{l}\text { Provide central support and } \\
\text { services. }\end{array}$ & \\
\hline & Total Scores & \\
\hline
\end{tabular}

\section{REFERENCES}

[1] I. E. Allen and J. Seaman. (January 2013). Changing course: Ten years of tracking online education in the United States. [Online]. Available: http://www.onlinelearningsurvey.com/reports/changingcourse.pdf

[2] D. Geller and C. Lee. (2013). SHRM survey findings: Virtual teams. [Online]. Available: http://www.shrm.org/research/surveyfindings/articles/pages/virtualtea ms.aspx

[3] V. Jakchaikul, "Application of learning management system for online learning modules," Applied Mechanics \& Materials, vol. 804, pp. 347-350, 2015.

[4] M. Courtney and S. Wilhoite-Mathews, "From distance education to online learning: Practical approaches to information literacy instruction and collaborative learning in online environments," Jounral of Library Administration, vol. 55, no. 4, pp. 261-277, 2015.

[5] A. O. Alsadhan, S. Alhomod, and M. M. Shafi, "Multimedia based e-learning: Design and integratin of multimedia content in e-learning," International Journal of Emerging Technologies in Learning, vol. 9, no. 3, pp. 26-30, 2014.

[6] Edmodo. (2015). [Online]. Available: https://www.edmodo.com/

[7] Access Your Planner. [Online]. Available: https://support.edmodo.com/hc/en-us/articles/205004384-Access-Yo ur-Planner-Teacher-

[8] G. Carlson and R. Raphael. (2015). Let's get social: The educator's guide to Edmodo. ISTE. [Online]. Available: https://www.iste.org/handlers/ProductAttachment.ashx?ProductID=3 $579 \&$ Type $=$ excerpts
[9] Google Apps for Education. (2015). [Online]. Available: https://www.google.com/edu/products/productivity-tools/

[10] Edtech teacher. (2015). [Online]. Available: http://edtechteacher.org/gafe/

[11] G. Ferenstein. (2010). Why schools are turning to Google Apps. Mashable. [Online]. Available: http://mashable.com/2010/04/28/schools-google-apps/\#wNMTIcv1u $\mathrm{mq} 3$

[12] J. Johnson. (September 2012). What in the world is a MOOC? [Online]. Available:

http://www.washingtonpost.com/blogs/campus-overload/post/what-in -the-world-is-a-mooc/2012/09/24/50751600-0662-11e2-858a-5311df 86ab04_blog.html

[13] J. Manning. (April 2014). Comparing MOOC platform features. Stanford Teaching Commons. [Online]. Available: https://teachingcommons.stanford.edu/teaching-talk/comparing-mooc -platform-features

[14] J. Haber, MOOCS, Cambridge, MA: MIT Press, 2014, ch. 3, pp. 48-88

[15] Moodle Overview. (2015). [Online], Available: https://moodle.com/moodle-lms/

[16] B. Ramesh. (July 2015). Collaborative learning through Moodle [Online]. Available: http://blog.commlabindia.com/elearning-development/moodle-for-col loborative-learning-infographic

[17] W. Fenton. (June 2015). Moodle LMS. [Online]. Available http://www.pcmag.com/article2/0,2817,2486973,00.asp

[18] Olat. (2015). University of Zurich. [Online]. Available: http://www.olat.org/

[19] (2013). Classroom aid: Connecting dots of digital learning. Open Source LMS from University of Zurich. [Online], Available: http://classroom-aid.com/2013/09/27/open-source-lms-from-universit y-of-zurich/

[20] L. Biggers. (2009). Skia: Open source...Open minds. Learning Solution Magazine. [Online]. Available: http://www.learningsolutionsmag.com/articles/216/saki-open

[21] (2015). Learning management. Sakia. [Online]. Available: https://www.sakaiproject.org/learning-management

[22] Grails. (2015). Sakai plugin. [Online]. Available: http://grails.org/plugin/sakai

[23] EEE. (2015). UCI EEE. [Online]. Available: https://eee.uci.edu/online-learning/comparison.php

[24] QA Testing. [Online]. Available: https://docs.moodle.org/dev/QA_testing

[25] H. Baytiyeh, "Users' acceptance and use of Moodle: The community influence," International Journal of Information \& Communication Technology Education, vol. 9, no. 4, p. 40, 2013.

[26] P. Thibaut, "Social network sites with learning purposes: Exploring new spaces for literacy and learning in the primary classroom," Australian Journal of Language \& Literacy, vol. 38, no. 2, pp. 83-94, 2015.

[27] Apereo Foundation. (2014). End-user support resources. [Online]. Available:

https://confluence.sakaiproject.org/display/ESUP/End-User+Support + Resources

[28] C. Matheson. (2015). How Moodle's social networking features became a "virtual hangout" for students, Moodle News. [Onine] Available:

http://www.moodlenews.com/2010/how-moodles-social-networking-f eatures-became-a-virtual-hangout $\%$ E2\% $80 \% 9 \mathrm{D}$-for-students-by-cyto chromec/

[29] Olathe Public Schools. (August 2013). Moodle powered classrooms. Olathe Public Schools. [Online]. Available: http://departments.olatheschools.com/technology/files/2013/11/Comp lete-Guide-to-Moodle-OPS-August-2013.pdf

[30] edX.org. (2015). Open edX architecture. [Online]. Available: open.edx.org: https://open.edx.org/contributing-to-edx/architecture

[31] Mastering Assessments. [Online]. Available: https://support.edmodo.com/hc/en-us/articles/205009934-MasteringAssessments-Quizzes-Assignments-Polls

[32] C. Severance, J. Hardin, G. Golden, R. Crouchley, A. Fish, T. Finholt, B. Kirschner, J. Eng, and R. Allan, "Using the Sakai collaborative toolkit in e-research applications," Concurrency and Computation: Practice and Experience, vol. 19, no. 12, pp. 1643-1652, 2007.

[33] Add a co-teacher to your group (teacher). [Online]. Available: https://support.edmodo.com/hc/en-us/articles/205005304-Add-a-CoTeacher-to-Your-Group-Teacher- 
[34] F. Ozdamli, "An evaluation of open source learning management systems according to administration tools and curriculum design," International Educational Technology Conference, 2007.

[35] University of Massachusetts Amherst. (2015). An overview of the Moodle Gradebook. [Online]. Available: https://www.it.umass.edu/support/moodle/overview-moodle-grade-bo ok

[36] J. Manning. (April 2014). Comparing MOOC platform features. Stanford teaching commons. [Online]. Available: https://teachingcommons.stanford.edu/teaching-talk/comparing-mooc -platform-features

[37] Building and Running an edX Course. (2015). [Online]. Available: http://edx.readthedocs.org/projects/edx-partner-course-staff/en/latest/i ndex.html

[38] Moodle.

(2015).

[Online].

Available: https://docs.moodle.org/28/en/About_Moodle\#Always_up-to-date

[39] Iste-Edmodo. [Online]. Available: https://www.iste.org/handlers/ProductAttachment.ashx?ProductID=3 579\&Type $=$ excerpts

[40] N. Cavus and T. Zabadi, "A comparison of open source learning management systems," Procedia-Social and Behavioral Sciences, vol. 143, pp. 521-526, 2014.

[41] Duke University Duke Sakai Support. Statistics: Tracking users and resources [blog]. [Online]. Available: https://support.sakai.duke.edu/2012/02/28/how-to-use-statistics-track ing-users-and-resources/

[42] Access Your Planner. [Online]. Available: https://support.edmodo.com/hc/en-us/articles/205004384-Access-Yo ur-Planner-Teacher-

[43] P. Cannel, P. (n.d.), Cambridge, p. 9, 2014.

[44] Share a Folder. [Online]. Available: https://support.edmodo.com/hc/en-us/articles/205004304-Share-a-Fol der-Teacher-

[45] edX. (2015). Contact us - edX. [Online]. Available: https://www.edx.org/contact-us

[46] Moodle. (September 2015). Moodle - Open sourced learning platform. [Online].

Available: https://docs.moodle.org/29/en/Moodle_manuals

[47] O. G. Gamayunova, N. V. Vatin, A. V.Rechinskiy, and E. V. Razinkina, "Distance learning system Moodle for training of specialists in the field of civil engineering," Applied Mechanics \& Materials, 2014

[48] Google. (August 2015). Open edX announcements. [Online]. Available: https://groups.google.com/forum/\#!forum/openedx-announce

[49] L. Martin, D. R. Martínez, O. Revilla, M. J. Aguilar, O. C. Santos, and J. G. Boticario, "Usability in e-learning platforms: Heuristics comparison between Moodle, Sakai and dotLRN," in Proc. Sixth International Conference on Community Based Environments, Guatemala, pp. 12-16, February 2008.

[50] Self-Guided Resources. [Online]. Available: https://support.edmodo.com/hc/en-us/sections/200910994-Self-Guide d-Resources

[51] E. Lafuente. (September 2015). Moodle. [Online]. Available: https://github.com/moodle/moodle

[52] Post in a Community. [Online]. Available: https://support.edmodo.com/hc/en-us/articles/205009234-Post-in-a-C ommunity-Teacher-

[53] D. Keckan, (June 2014). Muddling through Moodle - E-learning industry. [Online]. Available: http://elearningindustry.com/muddling-moodle

[54] Edmodo Help Center. [Online]. Available: https://support.edmodo.com/hc/en-us

[55] Google.

$$
\text { (2015). [Online]. }
$$

Available: https://support.google.com/edu/classroom/?hl=en\#topic $=6020277$

[56] C. Chang, C. Liang. K Shu, and Y. Chiu, "Alteration of influencing factors of e-learning continued intention for different degrees of online participation," International Review of Research in Open \& Distance Learning," vol. 16, no. 4, pp. 33-61, 2015.

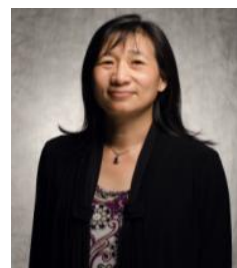

Li-Jen Y. Shannon residents in Huntsville, Texas, US. Dr. Shannon earned a degree of doctor in education of higher education executive leadership in 2007 and a master degree in industrial technology with minor in vocational technology in 1995 at Sam Houston State University, Texas, USA.

She taught computing foundation, Cisco networking, and Microsoft Professional courses from 2000 to 2007. She has been teaching an online master in instructiona technology program since 2007 at Sam Houston State University. In 2015, a doctor in instructional technology program has been approved by the Texas Higher Education Coordinating Board. Since then, she has been assigned to be a graduate advisor for the educational technology program under the Computer Science Department. She holds the position of an associate professor since 2014. Also, she has been serving as the director of Boosting Engineering Science Technology Robotics Hub at Sam Houston State University since 2011 . She has published more than 22 research papers in various peer reviewed journals relating to information system, robotics education, critical thinking practices, and mentorships. Her research areas are computing education alignments from secondary education to college level which involving with the promotion in science, technology, engineering, and mathematics fields.

Dr. Shannon has been the member of Education Special Interest Group of the Association of Information Technology Professionals, Information System and Computing Associated Professionals, and the International Association for Computer Information Systems. She served as a board member for the Education Special Interest Group of the Association of Information technology Professionals from 2009 to 2012 and assisted in organizing the international conferences for Information System Educators Conferences. She was awarded with Meritorious Paper of The 2011 Conference, Information Systems Educators Conference; Distinguished Paper of The 2010 Conference, Information Systems Educators Conference; Outstanding Paper in Other Business Disciplines Track, General Business Conference, April, 2009, Sam Houston State University; Best Paper of The 2009 Conference, Information Systems Educators Conference; Distinguished Paper of The 2007 Conference, Information Systems Educators Conference.

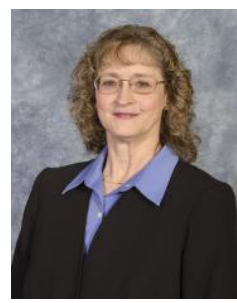

Marilyn P. Rice earned a doctorate in education degree in educational psychology with specialization in educational technology from Texas A\&M-College Station, TX, USA in 2002 and a master of education in administration in 1995 from Sam Houston State University in Huntsville, TX, USA.

She joined the Department of Curruculum and Instruction at Sam Houston State University (SHSU) in 2001 , leading the integration of technology into the curriculum for pre-service teachers. Serving as assistant chair of the Department of Curriculum and Instruction for seven years, and as coordinator of various academic programs throughout the years, she led the design, development, and implementation of the masters of education in instructioanl technology in 2007 and the doctorate of education in instructional technology in 2015. She holds the position of Professor since 2014. Initiating the introduction, training, and implemetation of Project Based Learning across the SHSU campus, she has served as director of the Center for Project Based Learning Research and Teaching. Her most recent paper is Developing Project Based Learning, Integrated Courses from Two Different Colleges at an Institution of Higher Education: An Overview of the Processes, Challenges, and Lessons Learned, by Rice and Shannon, published in conference proceedings, EDSIG (2015). Currently, she is the director of the doctorate in Instructional Technology Program at Sam Houston State University in Huntsville, TX, USA. Her research interests are creating more meaningful integration of technology in the curriculum, using the ever-changing tools for learners; and project based learning to give learners more voice and choice using current technologies.

Dr. Rice is a member of the International Society for Technology in Education, the Texas Computers in Education Association, and the Association of Information Technology Professionals. She received the Service Award from the SHSU College of Education in 2008. 